\title{
WILD PINEAPPLE (Ananas bracteatus (LINDL.), VAR. albus) HARVESTED IN FOREST PATCHES IN RURAL AREA OF VIÇOSA, MINAS GERIAS, BRAZIL: EXCELLENT SOURCE OF MINERALS AND GOOD SOURCE OF PROTEINS AND VITAMIN $C^{1}$
}

\author{
GALDINO XAVIER DE PAULA FILHO ${ }^{2}$, TIBÉRIO FONTENELLE BARREIRA ${ }^{3}$, \\ GILBERTO BERNARDO DE FREITAS ${ }^{4}$, HÉRCIA STAMPINI DUARTE MARTINO ${ }^{5}$, \\ HELENA MARIA PINHEIRO SANT' ANA $^{6}$
}

\begin{abstract}
In the rural region of the municipality of Viçosa, Minas Gerais, forest patches are encountered and they present a great diversity of wild and edible fruit, where wild pineapple (Ananas bracteatus (Lindl.), var. albus) is one of those of greatest occurrence. Given that, little is known about the nutritional characteristics of this fruit, the present study aimed to investigate the physical and physic-chemical characteristics, chemical composition (titratable acidity, total soluble solids, $\mathrm{pH}$, moisture content, ash, protein, lipids and dietary fiber), carotenoids ( $\alpha$-carotene, $\beta$-carotene, $\beta$-cryptoxanthin and lycopene), vitamin $\mathrm{C}$ (AA and DHA) by HPLC-DAD, vitamin E ( $\alpha-, \beta-, \gamma-, \delta$-, tocopherols and tocotrienols) by HPLC-fluorescence, and minerals (P, K, Ca, Mg, Cu, Fe, Zn, Mn, Na, Cr, Se and Mo) by ICP-AES. Fruits showed a moisture content average

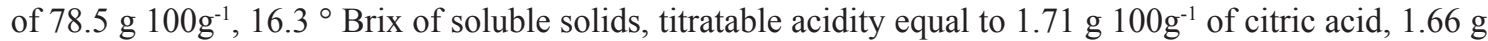

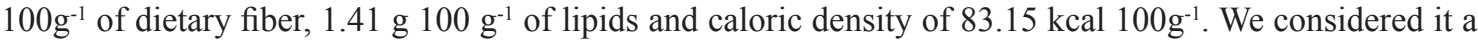

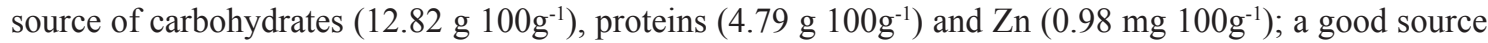

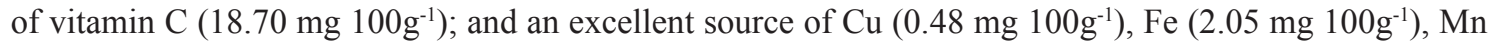

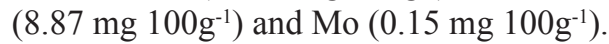

Index terms: Wild fruit, nutritional value, vitamins, nutrients.

\section{ABACAXI DO MATO (Ananas bracteatus (Lindl.), var. albus) COLHIDO EM FRAGMENTOS FLORESTAIS NA ZONA RURAL DE VIÇOSA, MINAS GERAIS: EXCELENTE FONTE DE MINERAIS E BOA FONTE DE PROTEÍNAS E VITAMINA C}

RESUMO-Na zona rural do município de Viçosa, Minas Gerais, encontram-se fragmentos florestais que apresentam grande diversidade de frutas silvestres e alimentícias, sendo o abacaxi do mato (Ananas bracteatus (Lindl.), var. albus) uma das frutas de maior ocorrência. Tendo em vista que pouco se conhece a respeito das características nutricionais dessa fruta, este trabalho teve por objetivo investigar a caracterização física, composição físico-química e química (acidez titulável, sólidos solúveis totais; $\mathrm{pH}$; umidade, cinzas, proteínas, lipídios e fibra alimentar); carotenoides ( $\alpha$-caroteno, $\beta$-caroteno, $\beta$-criptoxantina e licopeno) e vitamina $C$ (AA e ADA) por CLAE-DAD; vitamina $\mathrm{E}(\alpha-, \beta-, \gamma-, \delta$-, tocoferóis e tocotrienóis) por CLAE-fluorescência; e minerais ( $\mathrm{P}, \mathrm{K}, \mathrm{Ca}, \mathrm{Mg}, \mathrm{Cu}, \mathrm{Fe}, \mathrm{Zn}, \mathrm{Mn}, \mathrm{Na}, \mathrm{Cr}$, Se e Mo) por ICP-AES. Os frutos apresentaram em

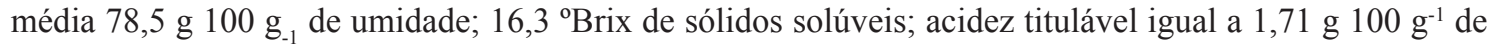

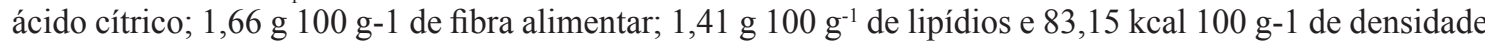

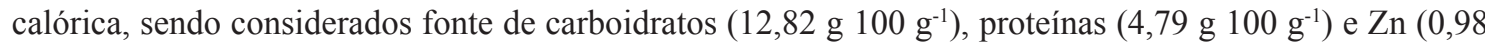

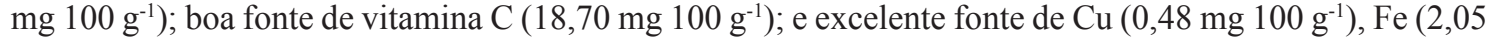

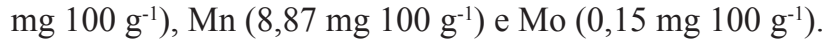

Termos para indexação: Fruta silvestre, valor nutricional, vitaminas, nutrientes.

\footnotetext{
${ }^{1}$ (Trabalho 031-15). Recebido em: 09-01-2015. Aceito para publicação em: 18-09-2015.

2Professor Assistente, Dep. de Educação, Campus Mazagão, UNIFAP, Macapá-AP. E-mail: galdino.filho@unifap.br

${ }^{3}$ Doutorando em Fitotecnia, Dep. de Fitotecnia, Laboratório de Silvicultura, UENF, Campos dos Goytacazes-RJ. E-mail: tiberiofbarreira@gmail.com

${ }^{4}$ Professor Associado, Dep. de Fitotecnia, Setor de Fruticultura, UFV, Viçosa-MG. E-mail: bernardo@ufv.br

${ }^{5}$ Prof ${ }^{a}$ Associada, Dep. de Nutrição e Saúde, Lab. de Nutrição Experimental, UFV, Viçosa-MG. E-mail: hercia@ufv.br

${ }^{6}$ Prof ${ }^{a}$ Associada, Dep. de Nutrição e Saúde, Lab. de Análise de Vitaminas, UFV, Viçosa-MG. E-mail: helena.santana@ufv.br
} 


\section{INTRODUCTION}

The fruit consumption has an important role in the healthy eating because it increases life expectancy, prevents chronic no infectious disease, due to the presence of minerals, vitamins and dietary fibre (ARA et al. 2014; COSTA et al. 2014). The protective effect that these foods have is attributed to the presence of compounds capable of capturing free radicals (antioxidants), highlighting the vitamins, phenolic compounds and carotenoids (KAUR et al. 2015).

Despite of this importance, in Brazil, the fruit consumption is still insufficient and inappropriate, and the daily intake is below the recommendation and this is lower in low-income families. The recommended daily intake per capita is $400 \mathrm{~g}$ of fruits (LI et al. 2012). However, the fruits have a high cost in the food groups and people in social vulnerability less consume them (HERSEY et al. 2015). This reality reinforces the need to appreciate wild fruits and the potential that they have.

The Atlantic forest is rich in fruits with nutritional potential that may be an alternative to improve the supply of nutrients to the general population (SILVA et al. 2014), extending this benefit to the rural population. However, non-conventional food groups, like fruits and vegetables, are still underutilized due to the lack of knowledge of their nutritional value (NANDAL; BHARDWAJ, 2014).

In the rural area of the municipality of Viçosa, there are forest patches of Atlantic Forest with high diversity of wild fruits. Although theses fruits are part of the local population eating habits, information about their nutritional value are scarce in the literature.

This study aimed to analyse the physical and physic-chemical characteristics, centesimal composition, occurrence and concentration of carotenoids, vitamin $\mathrm{C}$, vitamin $\mathrm{E}$ and mineral in wild pineapple fruits (Ananas bracteatus (Lindl.) var. albus) and to evaluate the nutritional contribution potential of this fruit for adults between 19 and 30 years old.

\section{MATERIAL AND METHODS}

Collection area, raw material, sampling and preparation of samples - The total area where the fruit harvest of wild pineapple was carried out is approximately $1.500 \mathrm{~m}$ of extension, in the wild environment of the rural area of Viçosa, Minas Gerais (south latitude 20 $0^{\circ} 5^{\prime} 14^{\prime \prime}$ " and west longitude $\left.42^{\circ} 50^{\prime} 40^{\prime \prime}\right)$. The fruit harvest was carried out in
January 2013. The harvest points were spaced from 200 to $400 \mathrm{~m}$. The fruit maturation was determined according to Donadio (2007) and defined by the red-orange peel colour and the characteristic smell.

After the harvest, the fruits were immediately transported to the Vitamins Analysis Laboratory, Department of Nutrition and Health of UFV, protected from light (wrapped in plastic bags and inside of cardboard boxes). The fruits were washed in water and dried with paper tower. Then, the fruits were peeled and the edible parts were homogenised in food processor, freeze-dried and stored in plastic bags in freezer at $-18 \pm 1^{\circ} \mathrm{C}$ until the analyses that happened in a maximum of 72 hours.

Physical characterization - The following measures were carried out in 30 wild pineapple fruits: length, diameter; total mass (TM), mass of the edible part or pulp mass (PM) and mass of the inedible part (peel mass). Then, the yield of the edible part was calculated using the equation: (TM/PM) x 100 .

Physic-chemical analysis - They were determined according to the rules of Adolfo Lutz Institute (2008). The total acidity (TA) was obtained by the neutralization volumetry, using standard solution of sodium hydroxide $0.1 \mathrm{~mol} / \mathrm{L}$ in the presence of phenolphthalein $1 \%$ solution $\left(\mathrm{C}_{20} \mathrm{H}_{14} \mathrm{O}_{4}\right)$ in ethanol, as an indicator. The soluble solids content (SS) was measured by the refractive index, using portable refractometer (Instrutherm, RTD-45), calibrated with distilled water, making the Brix correction to room temperature. The $\mathrm{pH}$ was measured using pHmetro (Ultra Basic, UB-10), calibrated with buffer solutions of 4 and 7 .

Analysis of the centesimal composition moisture, ash, proteins, lipids and total dietary fibre were determined in triplicate (AOAC, 2010). The moisture was determined in the oven (SP Labor ${ }^{\circledR}$, SP 200) at $65 \pm 1^{\circ} \mathrm{C}$, for 72 hours and ash in muffle (Quimis ${ }^{\circledR}, \mathrm{Q} 318 \mathrm{M}$ ) at $550{ }^{\circ} \mathrm{C}$, for 6 hours. Proteins were determined by the micro-Kjeldhal method, and the crude protein was calculated multiplying the nitrogen content $(\mathrm{N})$ by $6.25(\mathrm{AOAC}<2010)$. The total dietary fibre was determined by the nonenzymatic gravimetric methods with changes. The total carbohydrates were calculated by the difference between 100 and the sum of protein, lipid, moisture, ash and fibre fractions (IBGE, 1999). The caloric density was estimated considering the conversion factors of 4, 9 and $4 \mathrm{kcal}$ per $\mathrm{g}$ for carbohydrates, lipids and proteins, respectively (FRARY; JOHNSON, 2005).

Carotenoids analysis - the occurrence and concentration of $\alpha$-carotene, $\beta$-carotene, lycopene and $\beta$-cryptoxanthin were explored. The extraction 
was carried out according to the method proposed by Rodriguez-Amaya et al. (1976) and the analyses were carried out by high performance liquid chromatography (HPLC) with diode-array detection (DAD). The vitamin A concentration was calculated according to the recommendations of U. S. Institute of Medicine (2001).

Vitamin C analyses - The occurrence and concentration of ascorbic acid (AA) and dehydroascorbic acid (DHA) were explored. The vitamin $C$ extraction and analyses were carried out by (HPLC-DAD), according to the conditions proposed by Campos et al. (2009), with changes. The vitamin $\mathrm{C}$ total concentration was calculated by the sum of the AA and DHA concentrations.

Vitamin $\mathbf{E}$ analyses - The occurrence and concentration of $\alpha-, \beta-, \gamma-$ and $\delta$ - tocopherols and tocotrienols were investigated, as proposed by Pinheiro-Sant'Ana et al. (2011), in HPLC system with fluorescence detector. The vitamin $\mathrm{E}$ total concentration was calculated by the sum of vitamin E compounds in the fruits.

Mineral Analyses - Inductively Coupled Plasma Atomic Emission Spectrometry (ICP-AES) determined the concentration of $\mathrm{P}, \mathrm{K}, \mathrm{Ca}, \mathrm{Mg}, \mathrm{Zn}$, $\mathrm{Mn}, \mathrm{Fe}, \mathrm{Cu}, \mathrm{Na}, \mathrm{Cr}$, Se and Mo, according to the method proposed by Gomes and Oliveira (2011).

Determination of nutritional contribution

- The nutritional contribution potential was estimated based on the Recommended Dietary Allowance (RDA), for adults with age between 19 and 30, according to the recommendations of U. S. Institute of Medicine (2001). The fruit portions were calculated according to the 'Guia Alimentar para a População Brasileira' (Food Guide for the Brazilian Population) (BRAZIL, 2008), considering the caloric density and the fruit portion equivalent to $70 \mathrm{kcal}$.

\section{RESULTS AND DISCUSSION}

\section{Physic, physic-chemical characterization and centesimal composition}

The wild pineapple fruit (Figure 01) has a slight resemblance to the conventional pineapple (Ananas comosus L.), var. 'Pérola'.

In table 01 , there are the results obtained for the physical characterization of the wild pineapple fruits, which showed similar length, diameter and weight to the conventional pineapple, var. 'Pérola'. The wild pineapple showed average mass of $687.84 \mathrm{~g}$ (with crown) and pulp yield (edible mass) of $52.4 \%$.

The values found for SS were equivalent to $16.30{ }^{\circ} \mathrm{Brix}$ (Table 02), we highlight that is difficult to compare the values found here with other studies because the SS values are influenced by the environment, however due to the fact that this study was not carried out under controlled experimental conditions nor compared more than one specie in that environment, the presented result is an estimate obtained in the analysed sample (30 fruits).

The high acidity $\left(1.71 \mathrm{~g}\right.$ of citric acid $100 \mathrm{~g}^{-1}$ of pulp) was higher than the values found by Pinheiro et al. (2006) in pineapple juices, var. 'Pérola', ranging between 0.68 and $0.98 \mathrm{~g}$ of citric acid $100 \mathrm{~g}^{-1}$ of pulp. The SS/TA relation in the wild pineapple fruits was relatively high (9.53). This relation is one of the best ways to evaluate the flavour of a fruit, since it is an indicator of fruit quality in terms of maturation, flavour and industrial value (PIMENTA et al. 2014).

The information regarding the chemical composition and caloric density of the wild pineapple, presented in Table 02, show a moisture

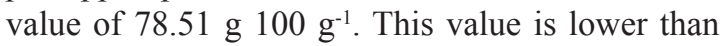
the pineapple moisture, var. 'Pérola' (TACO/NEPA/ UNICAMP, 2011), but it is a good indicator because it can represent a lower perishability of this fruit and a higher percentage of total dietary fibre, which in the fruits analysed in this study was $1.66{\mathrm{~g} 100 \mathrm{~g}^{-1}}^{-1}$ a concentration greater than the one found for the conventional pineapple, var. 'Pérola' (TACO/NEPA/ UNICAMP, 2011).

The caloric density of wild pineapple was higher than the banana (Musa paradisiaca L.)(78 Kcal $100 \mathrm{~g}^{-1}$ ) and orange (Citrus sinensis) (46 Kcal $\left.100 \mathrm{~g}^{-1}\right)$, which are between the ten most consumed fruits in Brazil (TACO/NEPA/UNICAMP, 2011; BUENO; BACCARIN, 2012). These results show that the wild pineapple can be a good option of daily intake for people who need to gain weight. However, for obese people, this intake should be controlled.

The carbohydrates concentration found in this study $(12.8 \%)$ is similar to the pineapple, var. 'Pérola' (12.3\%) and to other fruits available in the Brazilian Table of Food Composition (TACO/NEPA/ UNICAMP, 2011), such as the 'abiu' (Pouteria caimito Ruiz \& Pav.) (14.9\%), 'cajá' (Spondias lutea L.) $(11.4 \%)$ and cashew (Anacardium occidentale L.) $(10.3 \%)$

\section{Composition of carotenoids and vitamins}

The wild pineapple fruits showed total

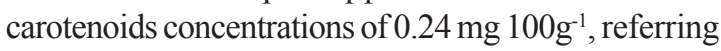
to the $\beta$-carotene that was the only compound found in this fruit, resulting in $20.0 \mu \mathrm{g} 100 \mathrm{~g}^{1}$ of vitamin A in RAE (Table 03). This value corresponds to 20 times more than the one mentioned to the frozen pulp of pineapple, var. 'Pérola' (NEPA/UNICAMP, 2011).

As for the vitamin $\mathrm{C}$ concentration, the results found for the wild pineapple (18.70 mg $\left.100 \mathrm{~g}^{-1}\right)$ 
are intermediated to the ones found by Berilli et al. (2014) for the conventional pineapple, cv 'Pérola' and 'Gold' (13.94 and mg 100 g ${ }^{-1}$, and 24,23 and mg $100 \mathrm{~g}^{-1}$, respectively).

There are no data available in the specialized literature about the vitamin $\mathrm{E}$ concentration in any variety of the pineapple fruits, which reinforces even more the importance of this study, where the fruits analysed showed $\beta$-tocopherol, $\alpha$-tocotrienol and $\beta$-tocotrienol, resulting in $28.05 \mu \mathrm{g} 100^{-1}$ of total vitamin $\mathrm{E}$.

\section{Mineral Composition}

Among the analysed minerals, we highlight the $\mathrm{K}, \mathrm{Ca}, \mathrm{Mg}$ and $\mathrm{Fe}$ (Table 04). However, the mineral concentration is not a safe indicator of nutritional value because some minerals like calcium, iron, zinc, copper and magnesium can form insoluble complexes with antinutritional factors (phytate, oxalate), decreasing its bioavailability (LEAL et al. 2010).

\section{nutrients}

Wild pineapple potential as a source of

According to Philip (2008), food can be classified as "source" of a nutrient when they supply from 5 to $10 \%$ of the Dietary Reference Intake (DRI), as "good source" when they supply from 10 to $20 \%$ of the DRI and "excellent source" when they supply more than $20 \%$ of the DRI.

The fruits analysed in this study were divided in portion of $70 \mathrm{kcal}$, according to the 'Guia Alimentar para a População Brasileira' (Food Guide for the Brazilian Population) (BRAZIL, 2008). Thus, $84 \mathrm{~g}$ of wild pineapple are necessary to provide a portion of $70 \mathrm{kcal}$ and it can be considered a source of carbohydrates and proteins because they showed $8.28 \%$ and $7.20 \%$ of these nutrients, respectively. The fruit can be considered a good source of vitamin $\mathrm{C}$ as it can supply $17.45 \%$ of the DRIs for adults.

In relation to the minerals, this fruit can be considered an excellent source of $\mathrm{Cu}, \mathrm{Fe}, \mathrm{Mn}$ and Mo; and Zn source (Table 05 ). .

The proof in this study that the wild pineapple show a significant concentration of nutrients suggest that strategies to introduce this fruit on the menu of children and adults can be developed when there is fruit availability, aiming at the possibility of supplying the deficiencies of some of these nutrients identified in other studies that were carried out in the same region, which identified risk factors associated with inadequate nutrition (SOUZA et al. 2012; FARIA et al. 2014).

TABLE 1 - Physical characteristics of wild pineapple fruits (Ananas bracteatus (Lindl.), var. albus) found in the rural area of Viçosa, Minas Gerais, Brazil (2013).

\begin{tabular}{lc}
\hline Characteristic & Average \pm Sd \\
\hline Diameter $(\mathrm{cm})$ & $9.46 \pm 0.65$ \\
Length $(\mathrm{cm})$ & $13.64 \pm 0.69^{*}$ \\
Fruit mass $(\mathrm{g})$ & $687.84 \pm 90.16$ \\
Peel mass $(\mathrm{g})$ & $329.17 \pm 68.44$ \\
Pulp mass & $358.66 \pm 63.82$ \\
Pulp yield (\%) & $52.36 \pm 6.69$ \\
\hline
\end{tabular}

* Without the crown. Sd: standard deviation

TABLE 2 - Physic-chemical and centesimal composition of wild pineapple fruits (Ananas bracteatus (Lindl.), var. albus) found in the rural area of Viçosa, Minas Gerais, Brazil (2013).

\begin{tabular}{|c|c|}
\hline Characteristic & Average $\pm \mathrm{Sd}$ \\
\hline$\overline{\text { Soluble solids (SS) ( }{ }^{\circ} \text { Brix) }}$ & $16.30 \pm 0.02$ \\
\hline Total acidity (TA) ( $\mathrm{g}$ of citric acid $\left.100 \mathrm{~g}^{-1}\right)$ & $1.71 \pm 0.23$ \\
\hline $\mathrm{SS} / \mathrm{TA}$ relation & $9.53 \pm 0.08$ \\
\hline $\mathrm{pH}$ & $3.50 \pm 0.05$ \\
\hline Moisture (g 100-1) & $78.51 \pm 1.19$ \\
\hline Total dietary fibre (g 100-1) & $1.66 \pm 0.03$ \\
\hline Lipids (g 100-1) & $1.41 \pm 0.12$ \\
\hline Proteins $\left(\mathrm{g} 100^{-1}\right)$ & $4.79 \pm 1.79$ \\
\hline $\operatorname{Ash}\left(\mathrm{g} 100^{-1}\right)$ & $0.80 \pm 0.13$ \\
\hline Carbohydrates (g 100-1) & $12.82 \pm 0.98$ \\
\hline Caloric density (Kcal 100-1) & $83.15 \pm 3.14$ \\
\hline
\end{tabular}

Sd: standard deviation. 3 repetitions pattern. 
TABLE 3 - Vitamin C, carotenoid and Vitamin E concentration of wild pineapple fruits (Ananas bracteatus (Lindl.), var. albus) found in the rural area of Viçosa, Minas Gerais, Brazil (2013).

\begin{tabular}{|c|c|}
\hline Characteristic & Average $\pm \mathrm{Sd}$ \\
\hline \multicolumn{2}{|l|}{ Vitamin C mg 100"-1 } \\
\hline AA & $15.06 \pm 1.81$ \\
\hline DHA & $3.64 \pm 2.57$ \\
\hline Total & $(18.70 \pm 2.99)$ \\
\hline \multicolumn{2}{|l|}{ Carotenoid mg 100-1 } \\
\hline$\alpha$-carotene & ud \\
\hline$\beta$-carotene & $0.24 \pm 0.08$ \\
\hline$\beta$-cryptoxanthin & ud \\
\hline Lycopene & ud \\
\hline Total & $(0.24 \pm 0.08)$ \\
\hline \multicolumn{2}{|l|}{ Vitamin E $\left(\mu \mathrm{g} 100^{-1}\right)$} \\
\hline$\alpha$-tocopherol & ud \\
\hline$\alpha$-tocotrienol & $8.55 \pm 0.22$ \\
\hline$\beta$-tocopherol & $15.98 \pm 6.25$ \\
\hline$\beta$-tocotrienol & $3.52 \pm 1.69$ \\
\hline$\gamma$-tocopherol & ud \\
\hline$\gamma$-tocotrienol & ud \\
\hline$\delta$-tocopherol & ud \\
\hline$\delta$-tocotrienol & ud \\
\hline Total & $(28.05 \pm 6.94)$ \\
\hline \multicolumn{2}{|c|}{ Vitamin A (RAE $\left.\mu \mathrm{g} 100 \mathrm{~g}^{-1}\right)$} \\
\hline Total & $(20.00 \pm 6.67)$ \\
\hline
\end{tabular}

Values expressed in fresh weight standard of 5 repetitions; ud: undetected. Sd: standard deviation

TABLE 4 - Minerals concentration in wild pineapple fruits (Ananas bracteatus (Lindl.), var. albus) found in the rural area of Viçosa, Minas Gerais, Brazil (2013).

\begin{tabular}{cc}
\hline Nutrient $\left(\right.$ in $\left.m g / 100^{-1}\right)$ & Average \pm Sd \\
\hline $\mathbf{P}$ & $0.23 \pm 0.05$ \\
$\mathbf{K}$ & $10.58 \pm 0.65$ \\
$\mathbf{C a}$ & $1.91 \pm 0.05$ \\
$\mathbf{M g}$ & $1.76 \pm 0.05$ \\
$\mathbf{C u}$ & $0.48 \pm 0.04$ \\
$\mathbf{F e}$ & $2.05 \pm 0.32$ \\
$\mathbf{Z n}$ & $0.98 \pm 0.11$ \\
$\mathbf{M n}$ & $8.87 \pm 1.54$ \\
$\mathbf{N a}$ & $0.07 \pm 0.01$ \\
$\mathbf{C r}$ & ud \\
$\mathbf{S e}$ & ud \\
$\mathbf{M o}$ & $0.15 \pm 0.03$ \\
\hline
\end{tabular}

Values expressed in fresh weight; average of 3 repetitions; ud: undetected. 
TABLE 5 - Potential of nutrient contribution of the wild pineapple (Ananas bracteatus (Lindl.) var. albus) found in the rural area of Viçosa, Minas Gerais, Brazil (2013) for adults (19 to 30 years old).

\begin{tabular}{ccc}
\hline \multirow{2}{*}{ Nutrient } & \multicolumn{2}{c}{ Wild pineapple $(\mathbf{1}$ portion $\mathbf{= 8 4 g}$ )* } \\
\cline { 2 - 3 } & Concentration/portion & \%** \\
\hline Carbohydrates & $10.77 \mathrm{~g}$ & 8.28 \\
Proteins & $4.03 \mathrm{~g}$ & 7.20 \\
Fibres & $1.39 \mathrm{~g}$ & 3.67 \\
Vitamin A & $16.8 \mathrm{~g}$ & 1.87 \\
Vitamin C & $15.71 \mathrm{~g}$ & 17.45 \\
Vitamin E $(\alpha$-tocopherol) & -- & -- \\
$\mathrm{P}$ & $0.19 \mathrm{~g}$ & 0.03 \\
$\mathrm{~K}$ & $8.89 \mathrm{~g}$ & 0.19 \\
$\mathrm{Ca}$ & $1.60 \mathrm{~g}$ & 0.16 \\
$\mathrm{Mg}$ & $1.48 \mathrm{~g}$ & 0.37 \\
$\mathrm{Cu}$ & $0.40 \mathrm{~g}$ & 44.8 \\
$\mathrm{Fe}$ & $1.72 \mathrm{~g}$ & 21.5 \\
$\mathrm{Zn}$ & $0.82 \mathrm{~g}$ & 7.48 \\
$\mathrm{Mn}$ & $0.74 \mathrm{~g}$ & 32.2 \\
$\mathrm{Na}$ & $0.06 \mathrm{~g}$ & 0.00 \\
$\mathrm{Cr}$ & $\mathrm{ud}$ & $\mathrm{ud}$ \\
$\mathrm{Se}$ & $\mathrm{ud}$ & $\mathrm{ud}$ \\
$\mathrm{Mo}$ & $0.13 \mathrm{~g}$ & 280 \\
\hline
\end{tabular}

* Based on the fruit portions that supply $70 \mathrm{Kcal}$ (BRAZIL, 2008); ** \% of calculated contribution based on the Recommended Dietary Allowance for adults between 19 and 30 years old, (U.S INSTITUTE OF MEDICINE, 2011), ud: undetected.

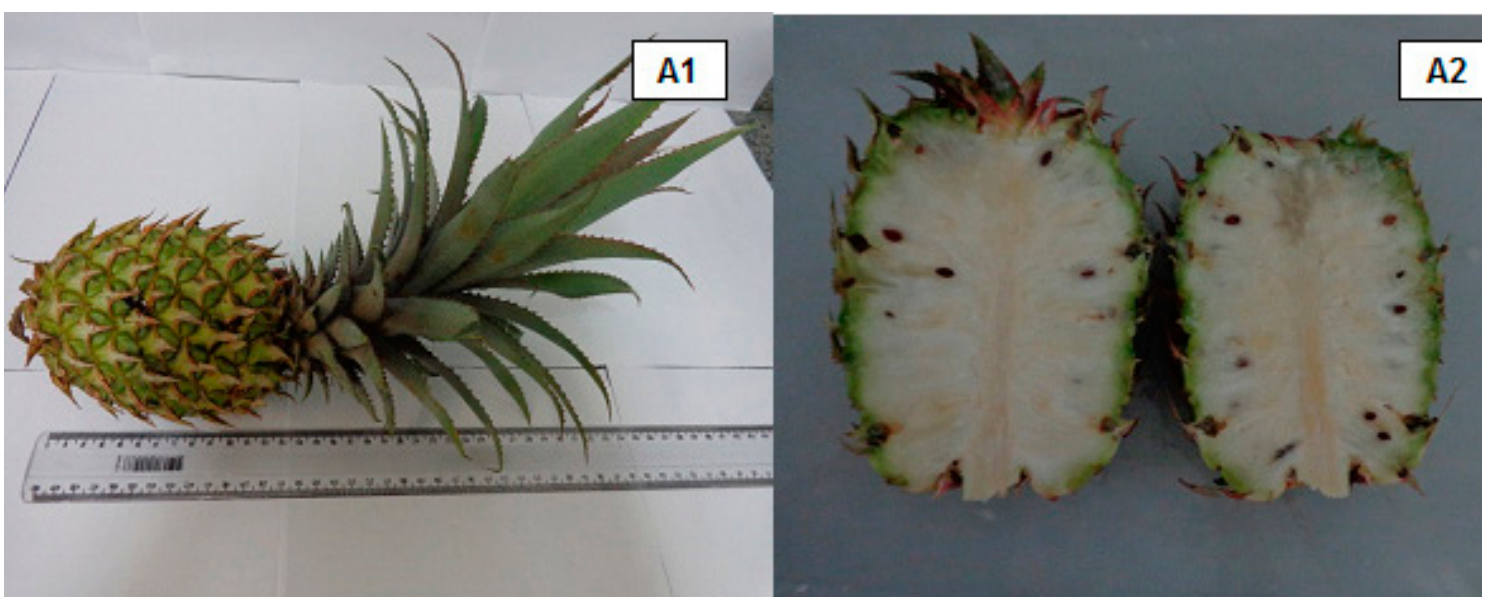

FIGURE 1-Whole fruit (A1) and longitudinal section (A2) of the wild pineapple (Ananas bracteatus (Lindl.), var. albus) found in the rural area of Viçosa, Minas Gerais, Brazil (A2). 


\section{CONCLUSIONS}

Wild pineapple fruits are source of carbohydrates, proteins and zinc; good source of vitamin $\mathrm{C}$; and excellent source of copper, iron, manganese and molybdenum.

Wild pineapple fruits can be an alternative to the nutritional supply of people living in the countryside, especially in the city of Viçosa, MG, Brazil, where they are found.

\section{ACKNOWLEDGEMENTS}

We thank to FUNARBE, FAPEMIG, CNPq and CAPES for the scholarships and financial support to carry out this research.

\section{REFERENCES}

AOAC - Association of Official Analytical Chemists. Official methods of analysis of AOAC international. $18^{\text {th }}$ ed. rev. Washington, 2010. v.2, $1170 \mathrm{p}$.

ARA, R.; JAHAN, S.; ABDULLAH, A. T. M.; FAKHRUDDIN, A. N. M.; SAHA, B. K. Physicochemical properties and mineral content of selected tropical fruits in Bangladesh. Bangladesh Journal of Scientific and Industrial Research, Daca, v.49, n.3, p.131-136, 2014.

BERILLI, S.S.; FREITAS, S.J.; SANTOS, P.C.; OLIVEIRA, J.G.; CAETANO, L.C.S. Avaliação da qualidade de frutos de quatro genótipos de abacaxi para consumo in natura. Revista Brasileira de Fruticultura, Jaboticabal, v.36, n.2, p.503-508, 2014.

BRASIL. Guia alimentar para a população brasileira: promovendo a alimentação saudável. Brasília: Secretaria de Atenção à Saúde, 2008. 210 p.

BUENO, G.; BACCARIN, J.G. Participação das principais frutas brasileiras no comercio internacional: 1997 a 2008. Revista Brasileira de Fruticultura, Jaboticabal, v.34, n.2, p. 424-434, 2012.
CAMPOS, F.M.; CHAVES, J.B.P.; AZEREDO, R.M.C.; OLIVEIRA, D.S.; PINHEIRO SANT'ANA, H.M. Optimization of methodology to analyze ascorbic and dehydroascorbic acid in vegetables. Química Nova, São Paulo, v.32, n.2, p.87-91, 2009.

COSTA, M.C.; BRITO, L.L.; LESSA, I. Práticas alimentares associadas ao baixo risco cardiometabólico em mulheres obesas assistidas em ambulatórios de referência do Sistema Único de Saúde: estudo de caso-controle. Epidemiologia e Serviços de Saúde, Brasília, v.23, n.1, p.67-78, 2014.

DONADIO, L.C. Dicionário das frutas. Jaboticabal: FUNEP, 2007. 300 p.

FARIA, E.R.; FARIA, F.R.; FRANCESCHINI, S.C.C.; PELUZIO, M.C.G.; SANT'ANA, L.F.R.; NOVAES, J.F.; RIBEIRO, S.M.R.; RIBEIRO, A.Q.; PRIORE, S.E. Resistência à insulina e componentes da síndrome metabólica, análise por sexo e por fase da adolescência. Arquivos Brasileiros de Endocrinologia \& Metabologia, São Paulo, v.58, n.6, p.610-618.

FRARY, C.D.; JOHNSON, R.K. Energia. In: MAHAN, L.K.; ESCOTT-STUMP, S. (Ed.). Alimentos, nutrição e dietoterapia. São Paulo: Rocca, 2005. p. 20-34.

GOMES, J.C.; OLIVEIRA, G.F. Fotometria de chama e espectrofotometria de absorção atômica. In: GOMES, J.C. e OLIVEIRA, G.F. (Ed.). Análises físico-químicas de alimentos: fotometria de chama e espectrofotometria de absorção atômica. Viçosa: Editora UFV, 2011. p. 244-247.

HERSEY, J.C.; CATES, S.C.; BLITSTEIN, J.L.; KOSA, K.M.; RIVERA, O.J.S.; CONTRERAS, D.A.; LONG, V.A.; SINGH, A.; BERMAN, D.A. Eat Smart, Live Strong Intervention Increases Fruit and Vegetable Consumption Among Low-Income Older Adults. Journal of Nutrition in Gerontology and Geriatrics, Durham, v.34, n.1, p.66-80, 2015.

IBGE - Instituto Brasileiro de Geografia e Estatística. Estudo nacional da despesa familiar - ENDEF: tabelas de composição de alimentos. 5.ed. Rio de Janeiro: IBGE, 1999.127 p. 
INSTITUTO ADOLFO LUTZ. Normas analíticas do Instituto Adolfo Lutz: Métodos químicos e físicos para análises de alimentos. 4.ed. São Paulo: IMESP, 2008. 1018 p.

KAUR, R.; KAUR, U.; WALIA, H. Evaluation of Free Radical Scavenging Activities of Aqueous Extracts of Fruits of Ziziphus mauritiana and Eriobotrya japônica Through in vitro Antioxidant Assays. Global Journal of Research and Rewiew, Bhopal, v.2, n.1, p.30-36, 2015.

LEAL, A.S.; GONÇALVES, C.G.; VIEIRA, I.F.R.; CUNHA, M.R.R.; GOMES, T.C.B.; MARQUES, F.R. Evaluation of mineral concentration and antinutritional factors phytate and oxalate in multimix from the Metropolitan Region of the City of Belo Horizonte/MG. Journal Brazilian Society Food and Nutrition, São Paulo, v.35, n.2, p.39-52, 2010.

LI, Y.; LI, D.; MA, C.; LIU, C.; HUI, D.; WEN, Z.; PENG, L. Consumption of, and factors influencing consumption of, fruit and vegetables among elderly Chinese people. Nutrition, New York, v.28, n.5, p.504-508, 2012.

NANDAL, U; BHARDWAJ, R.L. The Role of Underutilized Fruits in Nutritional and Economic Security of Tribals: A Review. Critical Reviews in Food Science and Nutrition, Amherst, v.54, n.7, p.880-890, 2014.

PHILIPPI, S.T. Pirâmide dos alimentos: fundamentos básicos da nutrição. Barueri: Manole, $2008.383 \mathrm{p}$.

PIMENTA, A.C.; SILVA, P.S.R.; ZUFFELLATORIBAS, K.C.; KOEHLER, H.S. Caracterização de plantas e de frutos de araticunzeiro (Annona crassiflora Mart.) nativos no cerrado matogrossense. Revista Brasileira de Fruticultura, Jaboticabal, v.36, n.4, p.892-899, 2014.

PINHEIRO,A.M.; FERNANDES, A.G.; FAI, A.E.C.; PRADO, G.M.; SOUSA, P.H.M.; MAIA, G.A. Avaliação química, físico-química e microbiológica de sucos de frutas integrais: abacaxi, caju e maracujá. Ciência e Tecnologia de Alimentos, Campinas, v.26, n.1, p.98-103, 2006.
PINHEIRO-SANT'ANA, H.M.; GUINAZI, M.; OLIVEIRA, D.S.; DELLA LUCIA, C.M., REIS B.L.; BRANDÃO, S.C.C. Method for simultaneous analysis ofeight vitamin $\mathrm{E}$ isomers in various foods byhigh performance liquid chromatography and fluorescence detection. Journal of Chromatography A, New York, v.1218, n.47, p.8496-8502, 2011.

RODRIGUEZ-AMAYA, D.B.; RAYMUNDO, L.C.; LEE, T.; SIMPSON, K.L.; CHICHESTER, C.O. Carotenoid pigment changes in ripening Momordica charantia fruits. Annals of Botany, Oxford, v.40, p.615-624, 1976.

SILVA, N.A.; RODRIGUES, E.; MERCADANTE, A.Z.; ROSSO, V.V. Phenolic Compounds and Carotenoids from Four Fruits Native from the Brazilian Atlantic Forest. Journal of Agricultural and Food Chemistry, Munique, v.62, v.22, p.50725084, 2014

SOUZA, N.N.; DIAS, M.M.; SPERANDIO, N.; FRANCESCHINI, S.C.C.; PRIORE, S.E. Perfil socioeconômico e insegurança alimentar e nutricional de famílias beneficiárias do Programa Bolsa Família no município de Viçosa, Estado de Minas Gerais, Brasil, em 2011: um estudo epidemiológico transversal. Epidemiologia e Serviços de Saúde, Brasília, v.21, n.4, p.655-662, 2012.

TACO/NEPA/UNICAMP. Tabela brasileira de composição de alimentos. 4. ed. rev. e ampl. Campinas: NEPA/UNICAMP, 2011. 161 p.

U. S. INSTITUTE OF MEDICINE. Dietary Reference Intakes (DRIs): vitamin A, vitamin $\mathrm{K}$, arsenic, boron, cromium, copper, iodine, iron, manganese, molybdenium, nickel, silicon, vanadium and zinc. Washington: National Academy Press, $2001.772 \mathrm{p}$. 